УДК 81’27 (94)

\title{
Verb Nomination
}

in the English Language:

Analytical Lexemes

\author{
Valeriy G. Shabaev* \\ Novosibirsk State Technical University \\ 20 K. Marx Av., Novosibirsk, 630073, Russia
}

Received 15.06.2016, received in revised form 07.07.2016, accepted 29.08.2016

Analytical verb-building (as a grammatical component of a language) is viewed as a typical characteristic feature of modern English language structure. Analytical derivation is equivalent to morphological word-building by its function (lexical component of a language). Analytical lexeme formation in four structure groups is shortly discussed in the paper presented.

Keywords: analytical word-building, analytical lexeme, phrasal verbs, pospositions, participles.

DOI: 10.17516/1997-1370-2016-9-10-2490-2495.

Research area: philology.

\section{Problems of the Analytical} Lexemes

The adoption of analytical system which replaced previously existed synthetic system has influenced lexical and grammar subsystems of the English language very much. Within lexical system analytical aspect has mostly manifested itself in analytical derivation as opposed to inflectional and word-building synthetic derivation.

Analytical word-building (grammar component of a language) is now viewed as a typical characteristic of modern English language structure. Analytical derivation is equivalent to word-building by its function (lexical component of a language). This idea has not been yet fully accepted because of numerous terminological interpretations and an existing 'standard' description of lexical means in the language.

V.Y. Plotkin described analytical derivation in modern English language using examples of derivational potential of the Russian stem cmap(bü) and its English equivalent old. Stems in the Russian language allow creating about 60 derivates with the help of affixes besides dozens of compound words, while the English stem can only allow about five derivates (oldish, olden, oldie, oldster). The English language does not allow expressing: (1) the concepts of cmapocmb, старик, старуха, стареи, старьё, старина, (2) processes старить, стареть, состариться, устареть, (3) characteristics стариковский, старческий, старинный, (4) circumstances встарь, исстари by synthetic means. In English

(c) Siberian Federal University. All rights reserved

* Corresponding author E-mail address: seangrey@yandex.ru 
to form such words adjective old + nouns man, boy, woman, chap, fellow, time, days, age, stuff, clothes, etc. or verbs be, get, grow, make, etc. are used (Plotkin, 1989, p. 199-204).

There are numerous examples of the difference in lexical derivation between the Russian and the English languages; there are no one-word equivalents of Russian synthetic derivates, including numerous verbs with prefixes (like взлететь) in the English language.

However, derivative function of the modern English language (which is vital for the lexis of the language in general) can only be weakly performed by means of synthetic derivation. The reason is that in the structure of the English language weak synthetic derivation is balanced by profound analytical derivation. Many researchers have stressed this characteristic of English lexical subsystem. See examples (Amosova, 1963; Vorontsova, 1960; Kunin, 1970; Smirniskij, 1956). Not the word, but the lexeme has to be viewed as an element of lexical system. It can be one-word or multi-word (analytical). When studying analytical verb lexemes we need to differentiate between their semantic and syntactic structure. Thus, we cannot rely on semantic properties and relations between components of a lexeme when defining the character of syntactic ties between them. They combine (according to some standard models) two components performing different functions - the main and the auxiliary one. Analytical verb lexemes usually have the following pattern: 'auxiliary + main component'. Auxiliary component is a verb, while the main component can belong to any of the four main parts of speech-verb, adjective, noun, or adverb. Thus, there are four types of analytical verb lexemes: 1$)$ verb+verb, usually with phrasal meaning (startsinging-is the English equivalent of the Russain 'заnemb'); see below part 3.2 and papers (Shabaev, 2010; Shabaev, 2011); 2) verb+adjective (kеер silent 'молчать', be afraid 'бояться', get rich 'богатеть', make angry 'cepдить'); see below part $\mathbf{3 . 1}$ and papers (Shabaev, 2010; Shabaev, 2011); 3) verb+noun (have a cry 'поплакать/всплакнуть', take a look 'взглянуть'); 4) verb+adverb (carry out 'выполнять', соте down 'спускаться', get over 'преодолевать'); see below part 3.3.

Syntactically the primary verb prevails over its adjunct component; however, in analytical lexemes such verbs (which are not numerous) act as auxiliary components, while the lexical meaning of the second component is more diverse and semantically the second component acts as the core of the lexeme. The fact that Russian verbs, counterparts of analytical lexemes, have stems, which are semantically equivalent to their second components, can serve as an indirect proof of auxiliary function of the verbs in the first three types. In the fourth type of analytical verb lexemes, verb + adverb, relations between the two components are more complex, because adverbs act as auxiliary components most often, while stem adverbs are not large in number. This explains the weak ability of adverbial component to act as a semantic basis of analytical lexemes, which results in verb component gaining more semantic weight.

This also explains why some Russian verbs have stems, which are semantically equivalent to the English verb component, but not adverb component. We can see that verbs are semantically important because of their considerable number more than 400 verbs act as analytical lexemes in this category, but only a few dozen are used intensively. Thus, analytical verb lexemes of verb + adverb type are different from the other three types by more equal distribution of semantic load between the two components and it is not always possible to define which of the components in the main and which is the auxiliary one.

Further analysis of analytical verb lexemes of the fourth type and the use of adverbs and 
homonymic postpositions presents a considerable scientific interest as the issue has not been properly studied.

\section{Problems of Eurysemy}

Typological revolution in the English language, which changes the ratio between one-word lexemes and analytical lexemes in favour of the latter causes inevitable stretch of language when words acquire new lexical meanings and new grammar meanings-ideas of beginning, process, perfectness, causativeness and passiveness (as compared to initial lexemes) with the help of derivative elements.

Firstly, because of the decrease in the number of words (one-word lexemes) each of them acquires a wider range of meanings. Secondly, because of the development of analytical verb lexemes there evolve words able to perform auxiliary grammar function within such lexemes. Auxiliary component of analytical verb lexem can never lose its lexical meaning. Semantics, which the element had before its transformation into auxiliary component of the analytical verb lexeme inevitably undergoes a considerable change because of its new function - it stretches so as to increase its semantic combinatorics. Therefore, stretch of language in the words that act as auxiliary components of analytical verb lexemes is conditioned by the fact that the English lexis becomes more analytical.

Consequently, not all the languages undergo this kind of stretch, besides it is not a purely lexical phenomenon as it is rooted in characteristics of the language's macrosystem. This semantic feature of auxiliary components of analytical verb lexemes has got the name of eurysemy (from Greek 'wide'). Notional breadth of such verbs is much wider and more conceptual than the characteristics mentioned for the most of the English verbs. There is also considerable difference between eurysemy and polysemy, which arises from metaphoric or metonymic transference.

Semantic structure of a polysemantic word consists of a number of separate meanings, which are not necessarily connected with each other (polysemy): it lacks integrity, so some of the meanings contradict the logical pattern, which however does not affect other meanings. Semantics of a polysemantic word cannot be characterized so as to embrace all its meanings.

Unlike polysemy, eurysemy can be characterized this way, although giving such characteristic is not an easy linguistic task. The meaning of a eurysemic word depends on the context, which eliminates all its other meanings except the contextual one. In speech eurysemy acquires particular meaning, but does not lose its variations. The language has two very close, but dramatically different phenomena - polysemy and eurysemy. The latter is usually viewed as some indefinite plurality. Dictionaries provide lengthy lists of different meanings, whose semantic diversity is so great that the use of word is not always clear. However, the phenomenon of eurysemy does not get enough attention. At the moment it is impossible to define the limits of the meaning of a eurysemic word (if they exist at all).

Without a context a word is either in the speaker's memory or in a dictionary, so it is viewed only as a language element. This is a purely linguistic problem as an ordinary native speaker never thinks which of the meanings of a polysemantic word is used in a certain context in speech. The wider meaning of the word does not change or disappear in a certain context, but stays in the speaker's subconsciousness and acts as the basis of any of its narrower meanings.

Some linguists (for example, R. Jakobson) state that a word has one 'general meaning' that refers to the language as a whole and a number of 'contextual meanings' used in speech. 
'Contextual meanings' of a polysemantic word are combinatorial variants of the general meaning. They evolve in speech under the influence of the word's environment. 'General meanings' are constant and do not depend on the context, so in speech they become acute as certain 'positional variants'. For example, the broad meaning of the verb GET is specified by the grammar of its auxiliary component - adjective, participle, adverb or preposition, whose lexical semantics is not so important.

There are a lot of eurysemic verbs in the English language (unlike nouns, an obvious example of which is the word thing), but only 10-12 of them form the core and play the leading role in building analytical verb lexemes. They are connected to each other by semantic and grammar ties that form a structural carcass of macrosystem of eurysemic words.The increase of percent of analytical lexemes in the language preconditioned appearance and development of a new macrosystem of eurysemic verbs, which have considerably changed the properties of the words it embraced.

\section{Core of Analytical Lexemes with the Verb GET}

Let us study the examples of phrasal verbs from original English texts in the following groups providing a brief description: 3.1. GET+Adjectives, 3.2. GET+Past Participles, 3.3. GET+Postpositions (example - 'GET OVER')

3.1. GET+Adjectives. The subject acquires new qualitative characteristic (condition) under external influence, which it cannot control or forecast. Grammar properties (concepts) perfectness/resultativeness;

passiveness (quasi-passive; medio-passive); causation. (1) Did you know, Putnam, that more murders are committed at 92 Fahrenheit than any other temperature? I read an article once. Lower temperatures, people are easygoing. Over 92, it's too hot to move. But just 92, people get irritable. (H. Essex, U.S. screenwriter) - (2) King David was old and advanced in years; and although they covered him with clothes, he could not get warm. (Bible: Hebrew, 1 Kings 1:1) - (3) Forget your troubles and just get happy. (T. Koehler, U.S. songwriter) - (4) A thousand friends when you're paying the bill, but none to be seen when you get ill. (Chinese proverb. Rhyme)

3.2. GET + Past Participle. Transition of the subject into (acquiring) a new state under external influence; semantic role of an actant - the subject is suffering the action. Grammar characteristics (concepts) - perfectness/resultativeness; passiveness (quasi-passive; medio-passive). (5) It is time to get drunk! So as not to be the martyred slaves of Time, get drunk; get drunk without stopping! On wine, on poetry, or on virtue, as you wish. (Ch. Baudelaire, French poet, critic) - (6) I can't get started with you. (I. Gershwin), U.S. songwriter) - (7) I always said if I lived to get grown and had a chance, I was going to try to get something for my mother and I was going to do something for the black man of the South if it would cost my life. (F. L. Hamer, African American civil rights activist) - (8) I got lost but look what I found. (I. Berlin), U.S. songwriter) - (9) I'm getting married in the morning, get me to the church on time! (A.J. Lerner, U.S. songwriter) - (10) I had heard so much about how hard it was supposed to be that, when they were little, I thought it would be horrible when they got married and left. (Anonymous Mother. As quoted in Women at a Certain Age, by Lillian B. Rubit, ch. 2) - (11) I went out there for a thousand a week, and I worked Monday, and I got fired Wednesday. (N. Algren, U.S. author) - (12) It was impossible after we got mixed together to tell an anti from a suffragist by her clothes. (S. Anthony, U.S. suffragist). 


\subsection{GET+Postpositions (на примере 'GET OVER')}

3.3.1. GET + OVER $\boldsymbol{a d v}$ The subject makes anachievementorgets someresult, ithassemantics 'at last', 'despite', 'nevertheless'. Grammar component-perfectness/resultativeness. $\underline{\text { Adverb }}$ is used in postposition and implies the idea of 'intention of the subject's action'. This idea is also rooted in the very nature of an adverb, whose task is to compliment to the meaning of the verb (adverb - 'at the verb'). Semantic field of an adverb forms the periphery of the verb's semantic field. See examples (14) and (16).

(13) How can we get over? The traffic's so busy." The new boats get people over to the island in half the time." Give me a push up, will you, I can't get my leg over. -переходить через дорогу, переправлять(ся) через реку, перелезать через стену. (14) When the weather's better, do (emphasis on the action) get over to see us [3].

3.3.2. GET + OVER prep. The subject acquires (or achieves) certain spatial and temporal characteristics (an object clause). Grammar component - syntactic orientation of the action on its circumstances. Prepositions as functional lexical units convey spatial and temporal idea of the action (including propositions as part of phrasal verbs). Prepositions specify nominative words, which follow them - object of action, character, place and time of the event. (15) The smallest boy was unable to get over the wall as fast as the others." You can get over the road more safely at the traffic lights. - How do you get a horse over a high fence? - The teacher got the children over the busy road safely. - (16) These new cars get over the miles so smoothly. All the horses got over the course, but two of them were badly hurt (Cortni, 2000, p. 254).

\section{Conclusion}

A typical characteristic of modern English as an analytical language is its tendency to expand its analytical features. In this paper we have presented examples of enlarging lexical corpus of the language through analytical verb lexemes. There are four ways:

1. Analytical verb lexemes, which contain eurysemic verbs (examples with the verb GET) plus nouns, adjectives or participles.

2. In such analytical verb lexemes - nouns, adjectives and participles (stems of derivational 'syntactic word') are notional components while verbs (word-building prefixes of derivational 'syntactic word') perform constructive and grammar functions.

3. Analytical verb lexemes, which contain a polysemantic verb (more than 400) and postposition (phrasal verbs) - an adverb or a preposition.

4. In analytical verb lexemes of type (3) adverbs play the role of a stem in derivates verb+adverb (verb - a suffixal word-building component); in derivates verb+preposition the verb is a stem component and preposition performs the function of a word-building component (suffix) of a derivational 'syntactic word'.

\section{References}

Amosova N.N. Osnovy anglijskoj frazeologii [The foundations of the English phraseology]. Leningrad, 1963. P. 113-119; 131-135.

Vorontsova G.N. Ocherki po grammatike anglijskogo yazyka [The essays on the English Grammar]. M., 1960. 400 pp.

Cortni R. Anglijskie frazovye glagoly [The English phrasal verbs]. M., 2000. P. 254.

Kunin A.V. Anglijskaya frazeologia [The English phraseology]. M., 1970. P. 224-233; 244-252.

Plotkin V.Ya. Stroj anglijskogo yazyka [The structure of the English language]. M., 1989. 239 pp.

$$
-2494-
$$


Smirnitskij A.I. Leksikologiya anglijskogo yazyka [Lexicology of the English language]. M., 1956. P. 220-222.

Shabaev V.G. Grammatikalizatsiya anglijskogo glagola GET [Grammaticalization of the English verb GET]. Novosibirsk, 2010. P. 204-213.

Shabaev V.G. Passivnye konstructsii s glagolami BE I GET pri sub'ektah v semanticheskih rolyah adversative I benefaktiva v sovremennom anglijskom yazyke [Passive constructions with the verbs BE and GET at the subjects in semantic roles of an adversative and benefactive]. V mire nauchnyh otkrytij 23, No. 11.7, 2011. P. 2074-2081.

\title{
Глагольная номинация
}

в английском языке:

\section{аналитические лексемы}

\author{
В.Г. Шабаев \\ Новосибирский государственный \\ технический университет \\ Россия, 630073, Новосибирск, пр. К. Маркса, 20
}

Рассматривается аналитическое образование глаголов (как грамматический компонент языка) в качестве типичной характерной особенности строя современного английского языка. Аналитическая деривация эквивалента морфологическому словообразованию по своей функциии (лексический компонент языка). В представленной статье кратко обсуждается аналитическое лексемообразование в четырёх структурных группах.

Ключевые слова: аналитическое словообразование, аналитическая лексема, фразовые глаголь, послелоги, причастия.

Научная специальность: 10.00.00 - филологические науки. 